\title{
Recent research on factors influencing the quality of frozen seafood
}

\author{
Naho Nakazawa ${ }^{1} \cdot$ Emiko Okazaki $^{1}$ \\ Received: 9 July 2019 / Accepted: 21 January 2020 / Published online: 20 February 2020 \\ (c) The Author(s) 2020
}

\begin{abstract}
In this review, recent findings related to various factors influencing quality properties of fish meat and its products during frozen storage are introduced. Many studies have indicated that protein denaturation is the factor determining the quality of frozen fish meat. Ice crystal size does not necessarily determine the quality of frozen fish meat because the tissue of meat reabsorbs water during the thawing process, unless it has been previously damaged by protein denaturation. However, the effects of ice crystals on the quality of thawed fish meat differ based on the fish species, post-mortem stages, protein denaturation, and processing conditions of the fish meat. In the case of frozen-thawed lightly salted fish meat, salting conditions greatly affect the water holding capacity of muscle and the ice crystal size. Also, in the case of frozen kamaboko, which is denatured protein gel, as the thawed water is not absorbed enough by the protein gel, ice crystal size could be a determining factor of quality. The appropriate freezing and storage conditions required for maintaining quality must be based upon the characteristics of each seafood product.
\end{abstract}

Keywords Drip loss $\cdot$ Storage temperature $\cdot$ Protein denaturation $\cdot$ Thawing $\cdot$ Preservation $\cdot$ Ice crystal formation $\cdot$ Seafood

\section{Introduction}

The meat of fish and shellfish exhibits a higher moisture content than livestock meat, and the proteins, lipids, and tissue structures are highly unstable, leading to substantial quality changes during freezing and thawing. Further, these characteristics differ depending on the species, season, maturity level, and other factors, including differences in freezing tolerance. Moreover, the meat components of fish and shellfish are affected by the changes in the biochemical state of the meat which relate to stress, fatigue, freshness, freezing speed, storage temperature, temperature fluctuations, and drying and thawing conditions. These factors determine quality changes of frozen fish meat and should be considered during processing and utilization. Despite extensive research on the quality changes of frozen seafood, the factors influencing quality are complicated and there are still unresolved

Published with support by the Japan Society for the Promotion of Science (JSPS) KAKENHI Grant no. JP 262003.

Emiko Okazaki

eokazaki@kaiyodai.ac.jp

1 Department of Food Science and Technology, Tokyo University of Marine Science and Technology, Minato-ku, Tokyo 108-8477, Japan issues. In this review, recent findings on the factors affecting quality properties of fish and fish products during frozen storage are introduced.

\section{Behavior of proteins and water in fish meat during freezing and thawing}

A schematic representation of the changes in water and muscle proteins of fish meat during freezing, frozen storage, and thawing tissues is shown in Fig. 1 (Nakazawa and Fukuda 2012). In unfrozen muscle tissues of pre-rigor fish meat, the cellular fluids are firmly bound to intracellular muscle proteins and maintain the integrity of muscle cells or cell membranes (Love 1968; Shenouda 1980; Benjakul and Bauer 2001). The cellular fluids in muscle tissue gradually defuse into extracellular spaces with the progression of postmortem changes (Love 1968; Shenouda 1980). During the freezing process, the formation of ice crystals, dehydration of protein molecules, and increase in solid concentration in the muscle tissues are the factors that may promote quality deterioration (Shenouda 1980). The formation of ice crystals with a volume expansion of about $9 \%$ has a physical influence on the structural features of muscle tissues and thereby distorts the structure of meat (Ertbjerg and Puolanne 


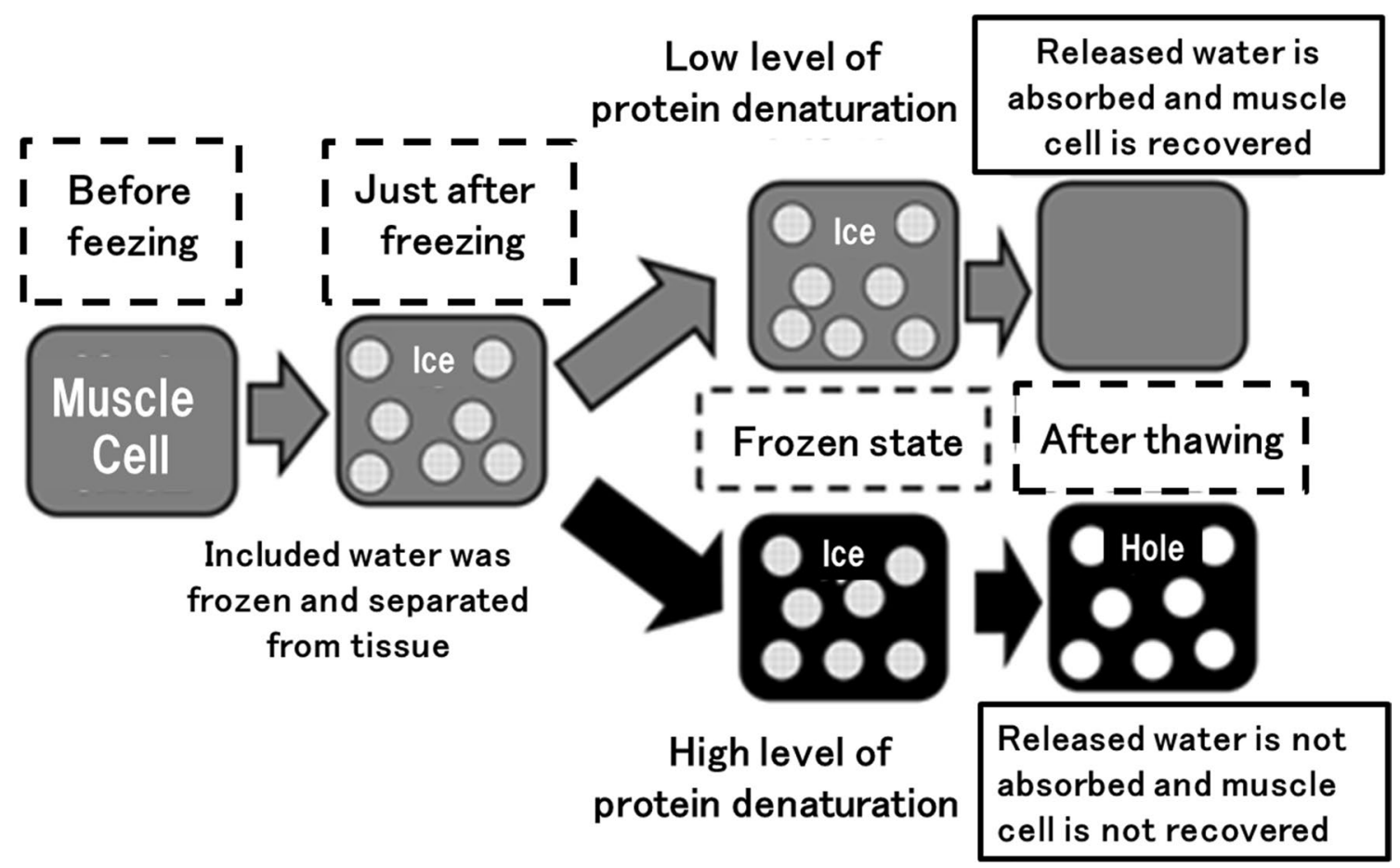

Fig. 1 Behavior of water and proteins in the process from freezing to thawing of muscle tissue of fish (schematic diagram). Adapted from Fig. 4.3.2 of Fukuda and Okazaki (2013)

2017; Leygonie et al. 2012; Ngapo et al. 1999; Martino et al. 1998). Foods with a high lipid content exhibit less expansion during freezing, as lipids contract when solidifying at low temperatures (Okazaki 2009). The freezing point of food (the temperature at which ice crystals begin to form) and the final temperature after freezing influence the amount of unfreezable water, affecting the quality degradation reaction (Tolstorebrov et al. 2016; Miyawaki 2018). These temperatures differ among fish species. For example, the freezing points of mackerel and squid are approximately $-1{ }^{\circ} \mathrm{C}$ and $-2.25^{\circ} \mathrm{C}$, respectively (Kato 1985), and the freezing point is $-0.9^{\circ} \mathrm{C}$ for cod (Miyawaki 2018). Moreover, the freezing end point varies widely from -35.7 to $-17.0^{\circ} \mathrm{C}$ depending on the fish species and freezing method (Tolstorebrov et al. 2016; Miyawaki 2018).

The ice crystal size depends on the freezing rate, and the location of ice crystal formation varies (intracellular and/or extracellular) depending on the freezing rate and the postmortem stages of the meat (Fukuda 2006). In general, rapid freezing produces a number of fine ice crystals in muscle cells, whereas slow freezing tends to produce large ice crystals outside of muscle cells. The formation and growth of ice crystals during freezing and cryopreservation destroys organelles and cells, releasing some proteinases and prooxidants and ultimately degrading muscle quality (Alizadeh et al. 2007; Benjakul and Bauer 2001; Leygonie et al. 2012).
Freeze-concentration accompanying the formation of ice crystals promotes reactions in the unfrozen phase, characterized by a high concentration of electrolytes and a reduced $\mathrm{pH}$, and myofibrillar proteins are denatured (Connell 1968). In addition, enzymatic reactions and autoxidation also proceed more easily with the formation of a freeze-concentrated phase during freezing (Leygonie et al. 2012).

In the thawing process, ice crystals melt, and the tissue reabsorbs the water, unless the muscle protein is damaged by denaturation. Ultimately, a state of muscle tissue similar to that prior to freezing is restored (Fukuda 1996; Ngapo et al. 1999). However, when muscle proteins are frozen and denatured, the water holding ability decreases and traces of ice crystals remain as empty spaces after thawing, resulting in incomplete restoration of muscle tissues, and affecting sensory issues of muscle foods such as drip loss, softer texture, gaps, and changes in taste and flavor (Fukuda 1996; Ngapo et al. 1999; Okazaki 2009). As described later, in the case of kamaboko (a typical Japanese surimi-based product), which is a heat-denatured protein gel without the organized structure of muscle tissue, the ice crystals in kamaboko at slow freezing can be larger than those in fish meat tissue; the thawed and dissolved water is only partially absorbed by the protein, voids formed by ice crystals often remain intact, and drip during thawing increases (Jia et al. 2019). 


\section{Quality changes of fish meat during freezing and frozen storage}

\section{Effect of frozen storage temperature on protein denaturation and fish meat quality}

During frozen storage, the properties of proteins forming the structure of fish meat, such as muscle cell membranes, are greatly affected, resulting in alterations in the water holding capacity and texture (Shenouda 1980). This quality deterioration is affected by the freezing rate, freezing storage temperature, fluctuations in storage temperature, thawing conditions, and other factors. Among these factors, storage temperature is particularly important. It is required that frozen foods should be stored at $-18{ }^{\circ} \mathrm{C}$ or lower according to Codex International Food Standards (1989) and the International Refrigeration Association. However, it is impossible to suppress the quality deterioration under the conditions of general commercial freezers $\left(-20\right.$ to $\left.-25^{\circ} \mathrm{C}\right)$. It has been reported that the rate of protein denaturation during frozen storage increases exponentially as the storage temperature increases (Fukuda et al. 1981, 1982). The degree of freezing tolerance depends on fish species. For example, bigeye tuna and tilapia, which inhabit high-temperature environments, have a high freezing tolerance, whereas pectoral rattail and Alaska pollock, which live in low-temperature environments, tend to have a low freezing tolerance (Fig. 2) (Fukuda and Arai 1994; Fukuda 1996).

When the storage temperature is lowered to around $-40{ }^{\circ} \mathrm{C}$, the denaturation rate slows, and the interspecific differences are minimal (Fukuda and Arai 1994). Fish meat quality can be maintained for a long period, which can be attributed to less protein denaturation when ultralow temperature storage (below $-40{ }^{\circ} \mathrm{C}$ ) is used, while the quality deterioration of fish meat occurs rapidly and continually as the storage period at $-20^{\circ} \mathrm{C}$ is extended.

When myofibril proteins undergo denaturation, the water holding capacity decreases, muscle tissue does not completely restore during thawing, moisture that is not reabsorbed flows out as drip loss, and the quality deteriorates significantly. Temperature fluctuations during frozen storage promote protein denaturation in fish meat (Fukuda et al. 2006).

The oxidation and hydrolysis of lipids, color changes due to sugar and amino acid reactions, color fading of red-skinned fish involving in carotenoids, formation of formaldehyde, which affects protein denaturation, and other quality changes also depend on temperature, similar to the protein changes described above.

Cod is an example of a fish that exhibits a significant deterioration in quality at around $-20{ }^{\circ} \mathrm{C}$. In cod and

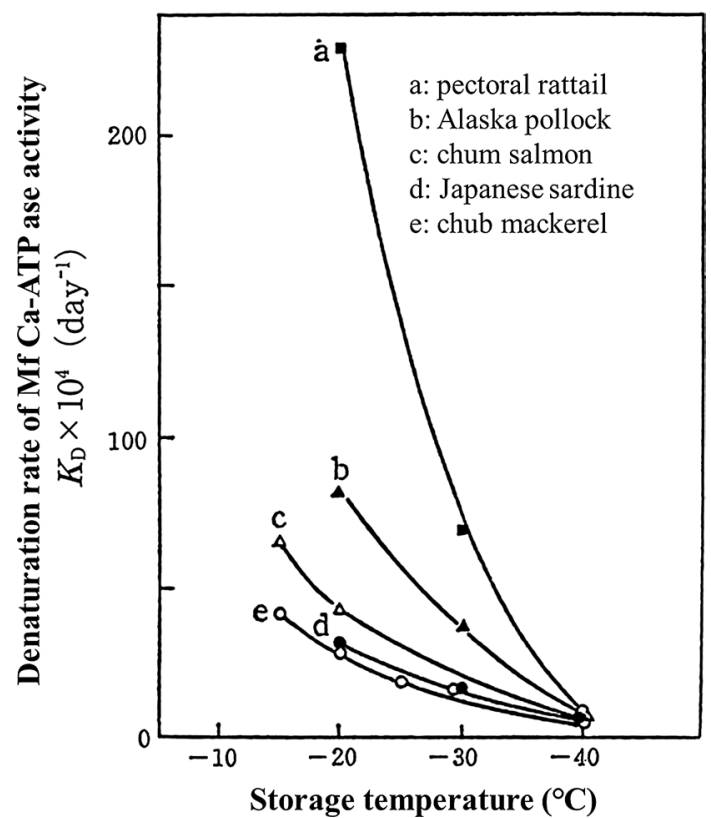

Fig. 2 Comparison of temperature dependence based on freeze denaturation rate constant $\left(K_{\mathrm{D}}\right)$ of myofibrillar Ca-ATPase in minced fish muscle for five different species. Reproduced from Fig. 3 in Fukuda (1996)

lizardfish species, formaldehyde is likely to form from trimethylamine oxide and denatured proteins during the process of freshness deterioration during frozen storage. This reaction progresses during frozen storage and results in a hard, watery, and spongy texture and a porous structure, which lowers the commercial value significantly.

There are slight differences in texture and odor when Atlantic salmon is stored at $-40{ }^{\circ} \mathrm{C}$ and $-25^{\circ} \mathrm{C}$, respectively, but the quality superiority due to low-temperature storage is not always observed (Indergard et al. 2014).

Low storage temperatures are required for maintaining the quality of tuna meat. The brilliant red color of tuna meat is due to myoglobin, which is a chromoprotein. Tuna meat in the 1950s, when distant longline fisheries were first established, exhibited browning during storage at insufficient temperatures, resulting in a low commercial value. Subsequent studies showed that storage at $-35{ }^{\circ} \mathrm{C}$ or lower can prevent the formation of met-myoglobin (Bito 1976). Since then, the temperatures of frozen storage cabinets have been reduced, and extremely low temperatures of $-50{ }^{\circ} \mathrm{C}$ or lower have been utilized in industrial settings.

As described above, the optimal storage temperature varies with the fish species and objectives. It is important to identify a suitable storage temperature for individual types of fish at which the quality is retained and energy is conserved at the same time. 


\section{Influence of freezing rate and chemical changes of frozen fish meat on restoration after thawing}

Freezing rate and storage temperature of food greatly influence the ice crystal size. However, studies of livestock meat (Añón and Calvelo 1980; Ngapo et al. 1999) have shown that the resilience of muscle tissues after thawing does not depend unconditionally on the freezing rate. Fukuda (1996) reported that cells in fish meat with large ice crystals at a slow freezing rate are restored to good conditions upon thawing, when the meat is stored at a sufficiently low temperature $\left(-40^{\circ} \mathrm{C}\right)$. This indicates that the formation of ice crystals is not the direct cause of damage, and that accompanying protein denaturation is an important factor. Figure 3 (Fukuda 1996) depicts the ice crystals of mackerel meat stored for 10 months with various freezing rates and storage temperatures as well as the restoration after thawing. Figure 4 (Fukuda et al. 1982) depicts the degree of protein denaturation.

In cod and swordfish meat, a new network structure forms easily during the formation of ice crystals, and the meat exhibits a sponge-like shape after thawing. Rapid freezing
Fig. 3 Effect of freezing rate and freezing storage temperature on the muscle fiber tissue of chub mackerel. Fillet of chub mackerel was initially frozen at $-20^{\circ} \mathrm{C}$ (for slow freezing) or $-80{ }^{\circ} \mathrm{C}$ (for quick freezing) for $20 \mathrm{~h}$ and subsequently stored at $-20{ }^{\circ} \mathrm{C}$ or $-40{ }^{\circ} \mathrm{C}$ for 10 months. Modified based upon Fig. 2 in Fukuda (1996)

Fig. 4 Effect of the freezing rate and storage temperature on protein denaturation (10 months of storage). Reproduced from Fig. 3 in Fukuda et al. (1982)

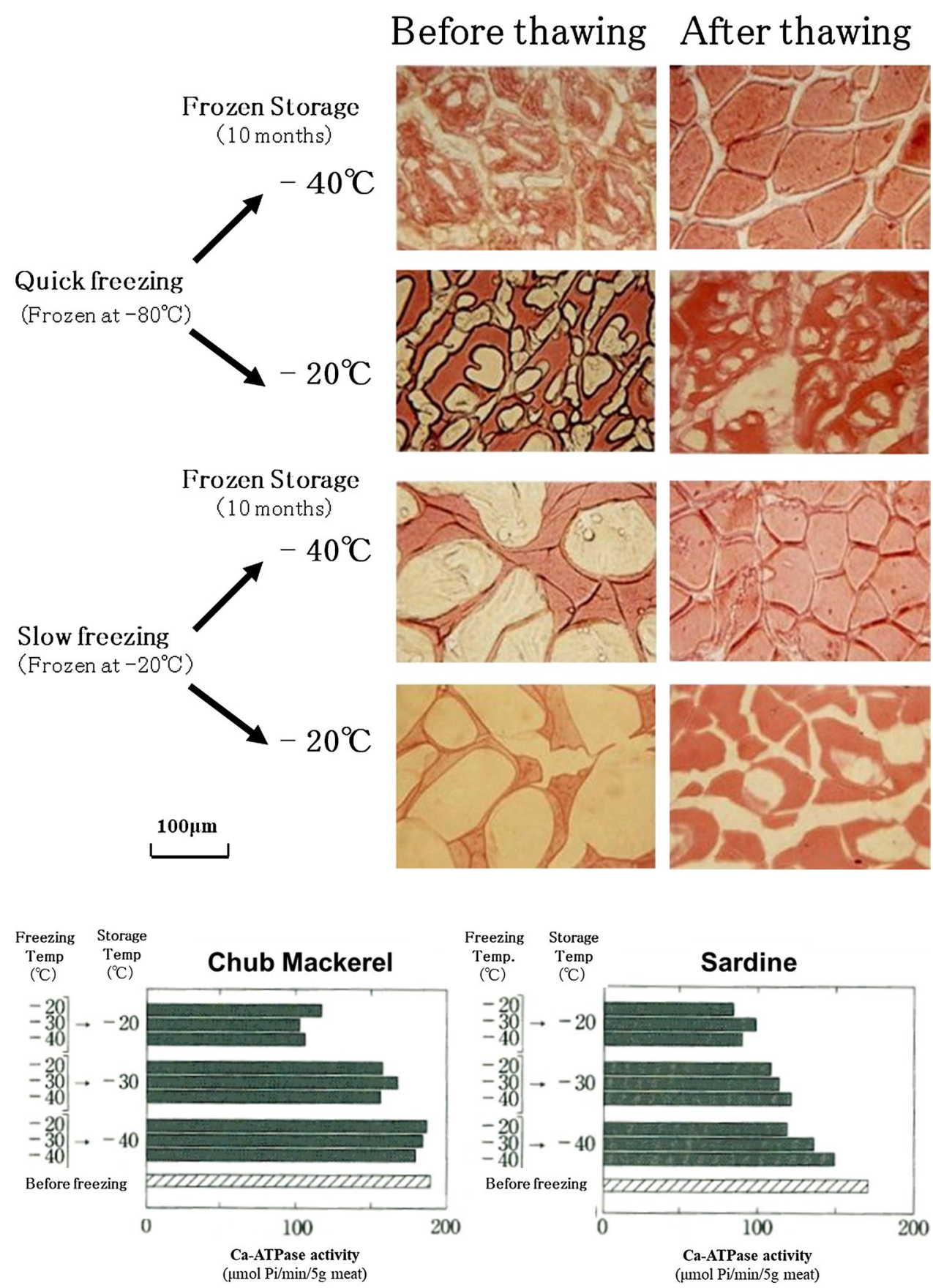


and low temperature storage $\left(-30^{\circ} \mathrm{C}\right.$ or lower $)$ are effective in preventing this phenomenon (Tanaka 1985; Tolstorebrov et al. 2016). Moreover, slow freezing causes the expansion of intercellular spaces in squid tissue (Ando and Miyoshi 2002).

Jiang et al. (2018a) examined the influence of different freezing methods on the quality of snakehead fillets and reported that freezing by extremely rapid temperature changes using liquid nitrogen caused tissue cracking and decreased the water holding capacity. For large fish (tuna), only parts near the surface freeze quickly, whereas the center portions freeze slowly; therefore, the ice crystal size also differs between the body surface and the central portions (Hanzawa and Fukuda 2006). However, these differences in ice crystal size do not necessarily have a decisive influence on the quality and price of tuna meat.

A study by Fukuda and Okazaki (2013) evaluated the effects of freezing rate on the $\mathrm{pH}$ of frozen tuna meat at different post-mortem stages (immediately after death, during rigor mortis, and after rigor mortis) and indicated that a lower freezing rate markedly affected the $\mathrm{pH}$ when tuna was frozen immediately after death. Further, it was found that the concentration of adenosine-5'-triphosphate (ATP) and lactic acid in tuna meat differed among different body regions, and the uneven distribution was attributed to the different freezing rates among the positions (Suzuki et al. 2015)
(Fig. 5). Based on these findings, differences in meat quality, particularly large fish between central and peripheral parts, were considered to be related to the progress of post-mortem changes prior to complete freezing, rather than a direct influence of ice crystal size (Fukuda and Okazaki 2013).

\section{Effect of fish freshness before freezing on the quality of frozen fish meat}

In fish meat, the degradation of ATP, decrease in $\mathrm{pH}$, and increase in $\mathrm{Ca}^{2+}$ concentration and osmotic pressure in muscle are related to the progression of post-mortem changes, and they are considered to be the main factors in protein deterioration, increase in susceptibility to proteolysis, and weakening of muscle structure (Delbarre-Ladrat et al. 2006). Furthermore, rapid decreases in the ATP concentration and $\mathrm{pH}$ are related to the stress of being caught combined with muscle fatigue during catching. In red meat fish containing high amounts of glycogen, such as sardine and mackerel, these changes are particularly marked (Fukuda et al. 1984).

Various reports have indicated that freshness also affects the formation of ice crystals during freezing. In Alaska pollack (Tanaka 1969), bonito (Tanaka et al. 1977), and Atlantic cod (Love and Haraldsson 1961; Love 1966), the structure of frozen tissues differed with different postmortem states
Fig. 5 The distribution of ATP and lactic acid in muscle from a cross section of bigeye tuna. ATP content was expressed as the ratio of ATP to total ATP-related compounds (\%). Modified from Figs. 2 and 4 from Suzuki et al. (2015)
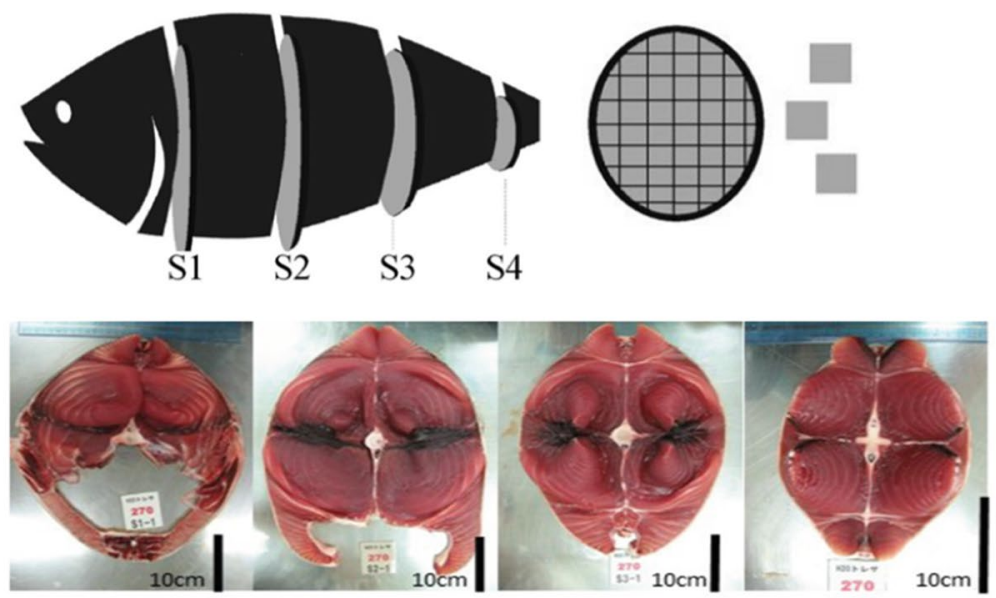

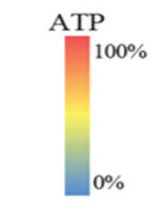

Lactic acid

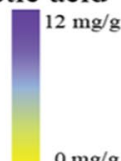

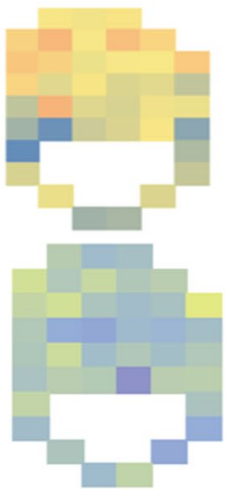
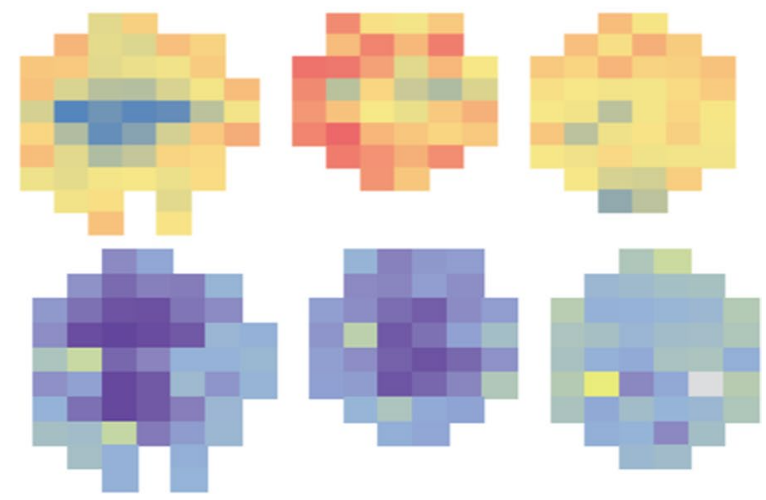
before freezing, and the ice crystals tended to grow extracellularly when the time interval prior to freezing was extended.

Love and Haraldsson (1961) predicted that an increase in free water due to protein denaturation promoted the formation of ice crystals, and Tanaka (1969) suggested that endomembrane changes were important determinants. Kaale and Eikevik (2013) reported that the state of ice crystals formed during the freezing process varied in Atlantic salmon depending upon the freshness and the portion of fish body. Kominami et al. (2014) showed quantitatively that postmortem changes in tissue properties, such as decreased water holding capacity and weakening of endomembrane, were significantly involved in ice crystal formation in frozen horse mackerel. Hashimoto and Takiguchi (2015) reported that larger ice crystals formed between the muscle cells of frozen spotted mackerel with the lowering of freshness, and there was a positive correlation between the ice crystal size and the amount of drip loss after thawing.

Conversely, it has been stated that fish meat frozen in an extremely fresh state before rigor mortis has excellent color and texture after thawing (Einen et al. 2002; Inohara et al. 2014). Recent studies have also shown that high $\mathrm{pH}$ and high ATP in fresh fish meat effectively suppressed changes in various properties during frozen storage. The inhibitory effect of ATP on protein denaturation is 10,000 times that of sucrose (Yoshioka and Arai 1986). The frozen denaturation of myofibrillar proteins (Ogata et al. 2012) and the formation of met-myoglobin (Inohara et al. 2013) are suppressed in fish meat with high ATP contents. The $\mathrm{pH}$ of fish meat before rigor mortis is generally high, around $\mathrm{pH} 7$, and it has been reported that protein denaturation in fish meat is suppressed at around $\mathrm{pH} 7-8$ with greater stability than that at $\mathrm{pH} 5-6$ (Fukuda et al. 1984; Hashimoto and Arai 1985).

Long-line tuna fisheries capture the tuna alive, and they are subjected to rapid nerve treatment and immediate exsanguination, followed by quick freezing and ultra-low temperature storage. However, tuna meat processed in this way often contains high levels of ATP, which is associated with muscular rigidity (thawing rigidity) when it is quickly thawed (Imamura et al. 2012). In the frozen tuna market, brokers use the above phenomenon to thaw frozen tuna tails in water quickly so that they can check the presence of thawing rigidity and evaluate the potential commercial value (Fukuda and Okazaki 2013). In fish meat, the ATP content and $\mathrm{pH}$ are maintained at high levels just after death and play an important role in stabilizing the protein in the frozen state.

Nakazawa et al. (2020) compared the rate of metmyoglobin formation in tuna meat at two different freshness levels during frozen storage, using bigeye tuna caught by long-line fishing and then frozen immediately onboard. They found that the metmyoglobin formation was remarkable in the meat with low ATP and low pH at $-40{ }^{\circ} \mathrm{C}$, while it was suppressed in the meat with high ATP and high $\mathrm{pH}$.
Based on these findings, high freshness of fish meat prior to freezing might have energy- and cost-saving implications for freezing and frozen storage.

\section{Quality changes of salted fish meat during frozen storage}

In recent years, reduction of salt content in salted fish meat has progressed due to a focus on health, but the preservative stability is low. Therefore, "Zuke" (consumed raw) and "Ichiya-boshi" (slightly salted dried fish for cooking), which are typical Japanese processed fish products prepared via mild salting, are sometimes distributed in a frozen state. However, such products often cause drip loss at the time of thawing, and the suppression has become an industrial concern. If the salt content is too high, protein denaturation and aggregation occur, which reduce protein solubility (Thorarinsdottir et al. 2011). In contrast, salting with a relatively low salt concentration (usually up to $1 \mathrm{~mol} / \mathrm{L}$ ) causes lattice expansion of the muscle filaments due to an increase in electrostatic repulsion, thereby improving the water holding capacity, yield, and textural properties (Ooizumi et al. 2003; Thorarinsdottir et al. 2004; Kin et al. 2010; Jiang et al. 2018b).

Though it is well known that the influence of salt on the protein properties and quality characteristics of fish meat depends on the salting conditions, the precise effects of salting on quality changes in fish meat after freezing have not been fully explicated. Historically, industrial processing procedures have been largely determined by experience. Therefore, a scientific basis for reducing drip loss in frozen, slightly salted fish meat is currently required.

Ichisaki et al. (2011) examined the relationship between salting condition and water separation after freezing and thawing using (instantly killed) horse mackerel meat; the results suggested that drip loss was suppressed at a salt concentration of $0.25 \mathrm{~mol} / \mathrm{kg}$ or greater and that the moisture content in the meat did not affect water separation significantly under these salting conditions (Fig. 6).

Jiang et al. (2018b) used scanning electron microscopy to study the frozen tissues of untreated tuna meat and tuna meat treated with $0.25-3 \mathrm{M} \mathrm{NaCl}$ solutions, and found that the shape of ice crystals differed substantially among these tissues. For instance, in the untreated tissues, large ice pillars formed parallel to the direction of muscle fibers, and the muscle fibers were highly compressed. According to Love (1968), growing ice crystals cannot develop freely in all directions within the muscle fiber of fish meat and are limited by the structured framework of the muscle tissue. In the case of salted fish meat treated with $0.5-1 \mathrm{M} \mathrm{NaCl}$, numerous spherical or elliptical ice crystals were uniformly dispersed throughout the cells (Fig. 7), and a small amount 


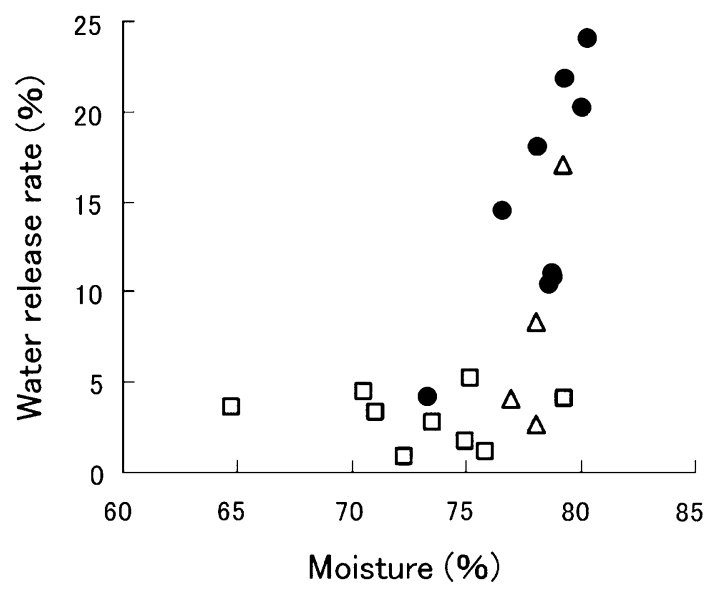

Fig. 6 Relationship between water release rate and moisture content in salted horse mackerel meat. Symbols indicate $\mathrm{NaCl}$ concentrations in the muscle meat, in which circles indicate a concentration of less than $0.1 \mathrm{~mol} / \mathrm{kg}$, triangles $0.1-0.25 \mathrm{~mol} / \mathrm{kg}$, and squares $0.25 \mathrm{~mol} / \mathrm{kg}$ or more. Adapted from Fig. 5 in Ichisaki et al. (2011) of thawing drip was generated. It was also demonstrated that the duration and temperature of frozen storage as well as freeze-thaw cycle had serious impacts on these phenomena (Jiang et al. 2019b). These results suggested that the thawed water was easily reabsorbed by the tissues at the time of thawing, and that the morphological properties of the ice crystals observed in the salted fish meat reflected changes in the protein properties due to $\mathrm{NaCl}$ as well as the changes in the hyperfine structure of tissues (Jiang et al. 2019a).

\section{Quality changes of surimi-based products during freezing and frozen storage}

Surimi-based products are produced from fish meat by mincing, kneading with salt, and heating to obtain a relatively uniform gel-like state formed by fish meat protein dissolved by salt and intertwined in a network structure. The quality of this product is easily deteriorated by freezing, and freezing damage is quite different from that of fish meat. In particular, Japanese traditional boarded kamaboko was
Fig. 7 Morphology of ice crystals in tuna meat with or without presalting by $1 \mathrm{M} \mathrm{NaCl}$ solution following freezing at $-20{ }^{\circ} \mathrm{C}$ for 1 week. a Micrographs observed by SEM. b Schematic illustration of the effect of proper presalting on the freezing stability of frozenthawed meat. Modified from Figs. $3 \mathrm{c}$ and 5 from Jiang et al. (2019b) (a)
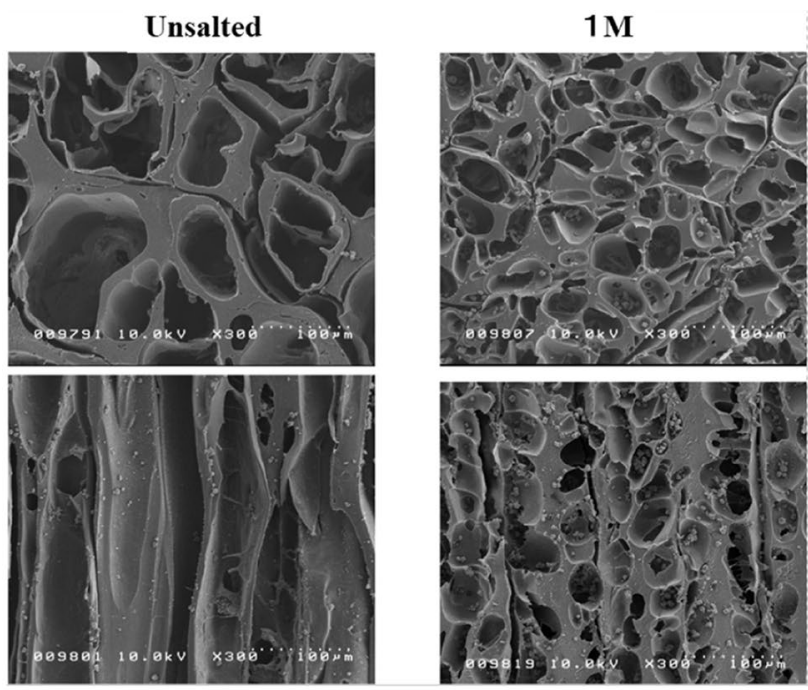

(b)

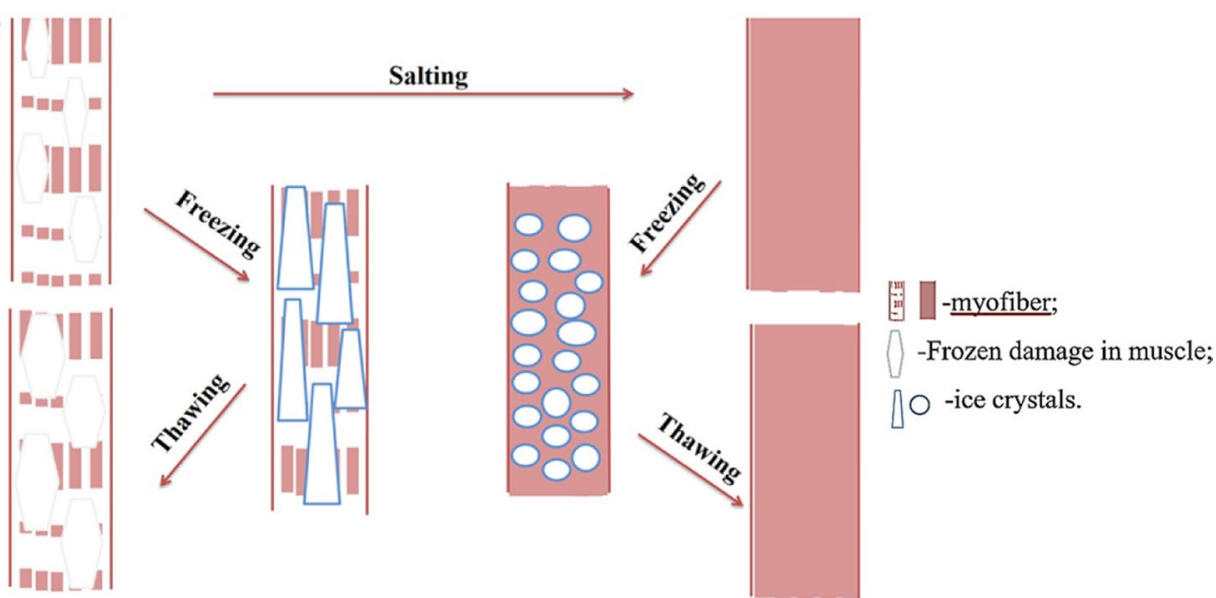


susceptible to the stress exerted by freezing and thawing and tended to exhibit water separation (Jia et al. 2018a). Because the consumption time of these products is concentrated around the New Year, frozen storage is necessary for scheduled production. Rapid freezing using liquefied gas and other techniques has recently been applied for manufacturing (Okazaki 2009). However, only limited information about the effects of various factors involved in the freezing tolerance of surimi-based products is available.

According to the studies of surimi gel as a model of surimi-based products at slow freezing, the ice crystal size varied with the freezing speed, as observed in fish meat, but resulted in ice crystals that were larger than those produced in fish meat (Jia et al. 2018b, c, 2019). In addition, water separated from the gel by freezing was not completely absorbed by tissues, even after thawing, and the spaces created by the ice crystals remained in the gel (Jia et al. 2018c). Although the state of drip generation could be suppressed by frozen storage at low temperatures, the ice crystal size relative to the freezing rate had a large influence on the quality of frozen surimi gel (Jia et al. 2019). The different effects of freezing on the quality of fish meat and surimi gel can be attributed to several factors. The muscle cells of fish meat are surrounded by membranes and have a regular structure, but the surimi gel is a smooth gel-like food without a defined structure.

Heating during processing of gel product is another factor that is generally associated with differences in protein denaturation. In the case of surimi gel, when a directly heated gel $\left(90^{\circ} \mathrm{C}\right.$ for $\left.30 \mathrm{~min}\right)$ and a two-step heated gel $\left(30{ }^{\circ} \mathrm{C}\right.$ for $60 \mathrm{~min}$, followed by $90{ }^{\circ} \mathrm{C}$ for $30 \mathrm{~min}$ ) were compared, larger ice crystals (Fig. 8) and greater drip loss (Fig. 9) were observed in the two-step heated gel than in the directly heated gel, suggesting that this was due to both an increase in surface hydrophobicity (Akahane and Shimizu 1990) and differences created by increased free water in the gels between the two types of gel (Akahane and Shimizu 1990; Jia et al. 2019).

It is known that starch may be added to surimi-based products to improve the water holding capacity (Yamazawa
Fig. 8 Ice crystal observation of surimi gels by direct heating and two-step heating after slow freezing and subsequent frozen storage at $-40{ }^{\circ} \mathrm{C},-20^{\circ} \mathrm{C}$, and $-10{ }^{\circ} \mathrm{C}$ for 1 -week. Reproduced from Fig. 3 in Jia et al. (2019)
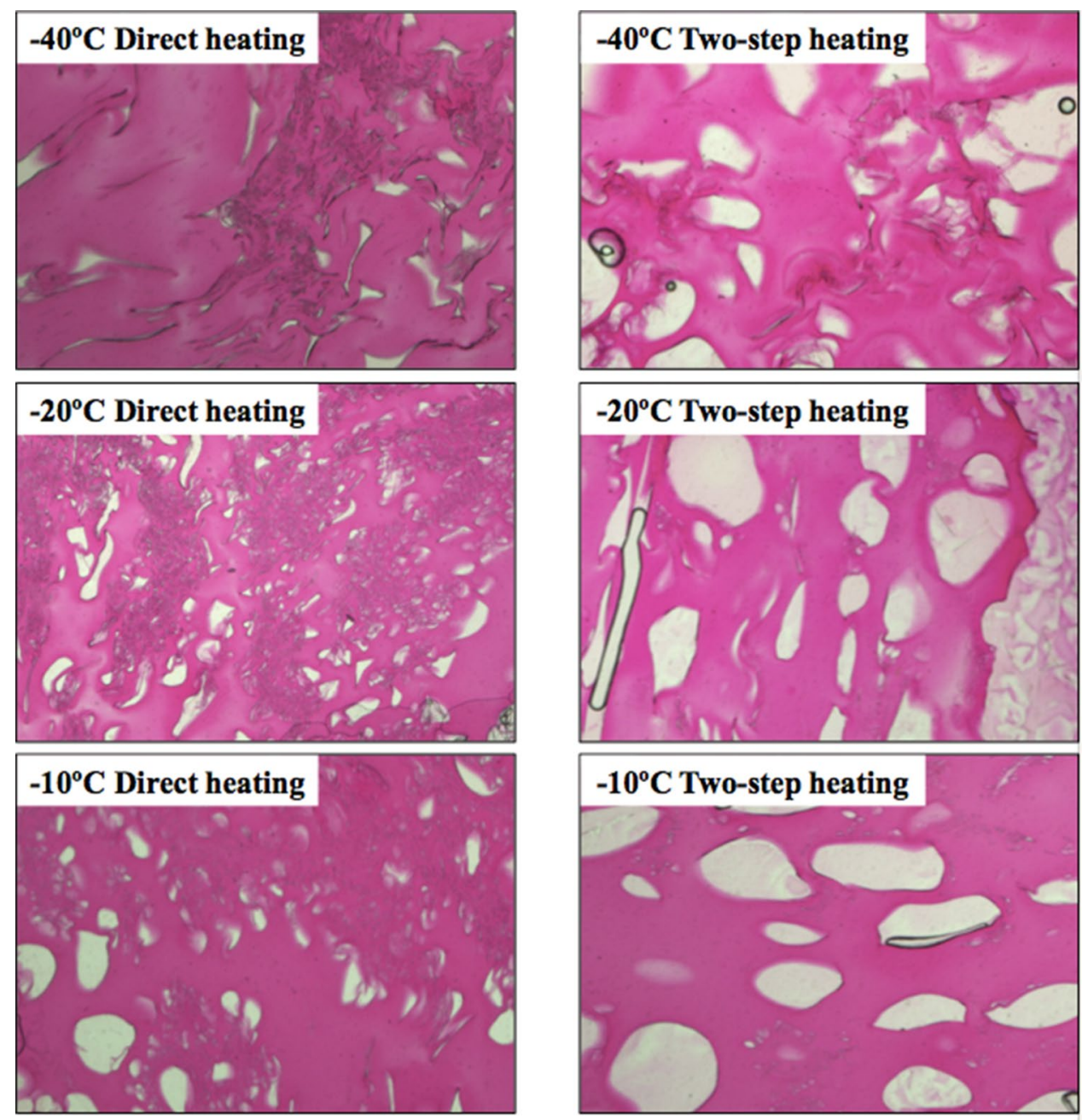

$\vdash 100 \mu \mathrm{m}$ 


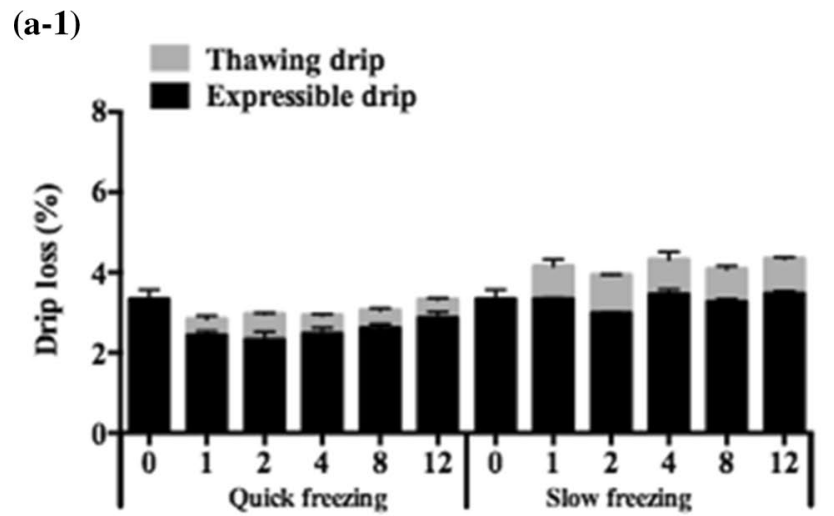

Frozen storage time (week)

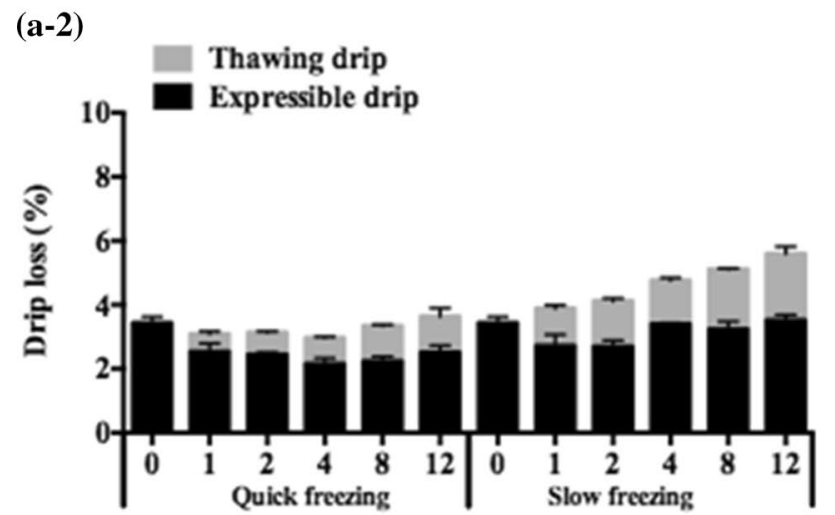

Frozen storage time (week)

(a-3)

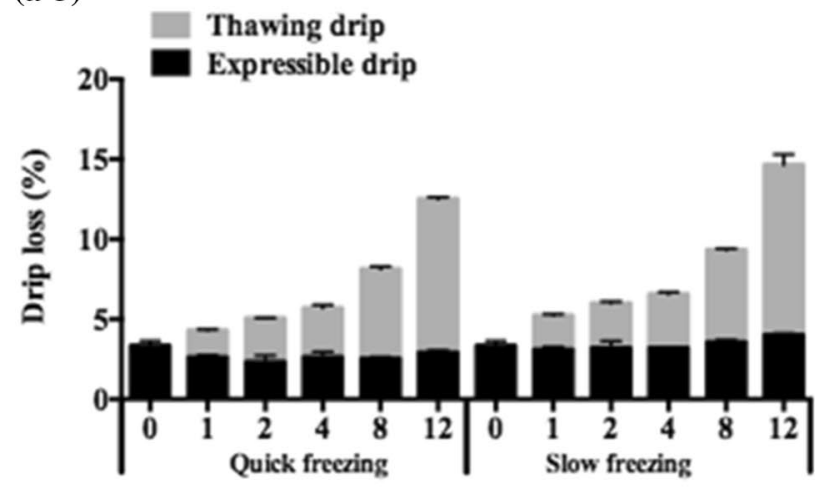

Frozen storage time (week)

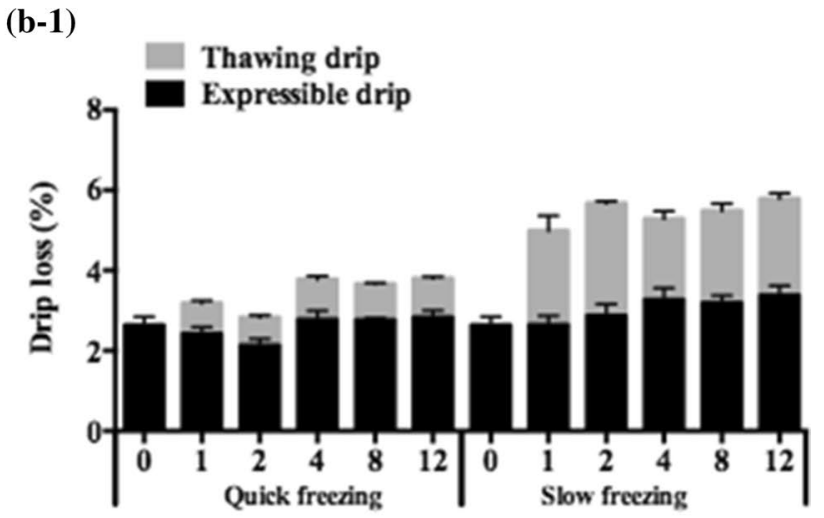

Frozen storage time (week)

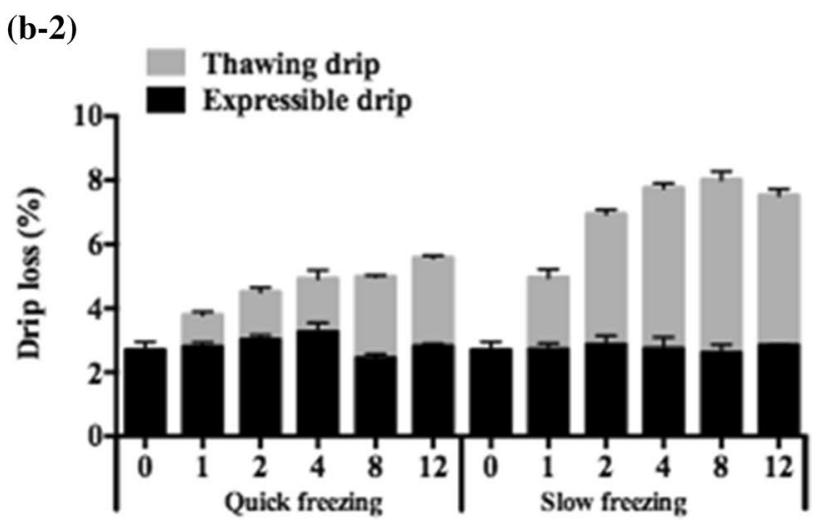

Frozen storage time (week)

(b-3)

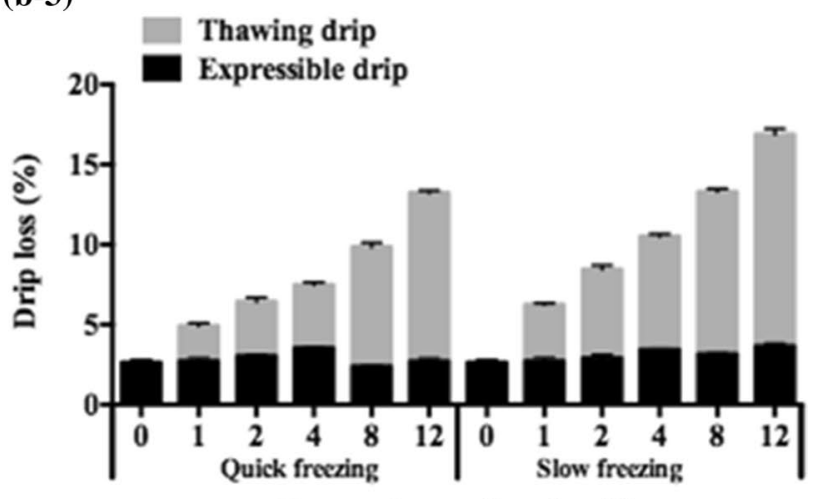

Frozen storage time (week)

Fig. 9 Changes in drip loss of direct heated gels (a) and two-step heated gels (b) before and after 12 weeks of frozen storage at $-40{ }^{\circ} \mathrm{C}(1)$; $-20{ }^{\circ} \mathrm{C}(2)$ and $-10{ }^{\circ} \mathrm{C}(3)$. Data are shown as mean \pm standard deviation. Reproduced from Fig. 9 in Jia et al. (2019)

1991). However, with slow freezing, the water holding capacity decreased due to the disintegration of starch particles (Fig. 10). Further, under some freezing conditions, the addition of starch could increase drip loss (Jia et al. 2018 b c). Various properties, including both gelatinization characteristics and retrogradation properties of the added starch, significantly affect the formation of ice crystals (Jia et al. 2018c). When starch-containing gels were frozen after setting, no disintegration was found in the starch particles and the water derived from ice crystals was absorbed by starch particles via heating after thawing; additionally, the water holding capacity improved compared to that of the conventional method (freezing after heating) (Jia et al. 2018c).

Furthermore, emulsification of surimi with fish oil contributed to the formation of smaller and more uniform ice 
Fig. 10 Microscopic observation of frozen heat induced surimi gel containing potato starch before and after thawing. Purple and white regions in thawed gel indicate starch granules and structural damage caused by ice crystal formation, respectively

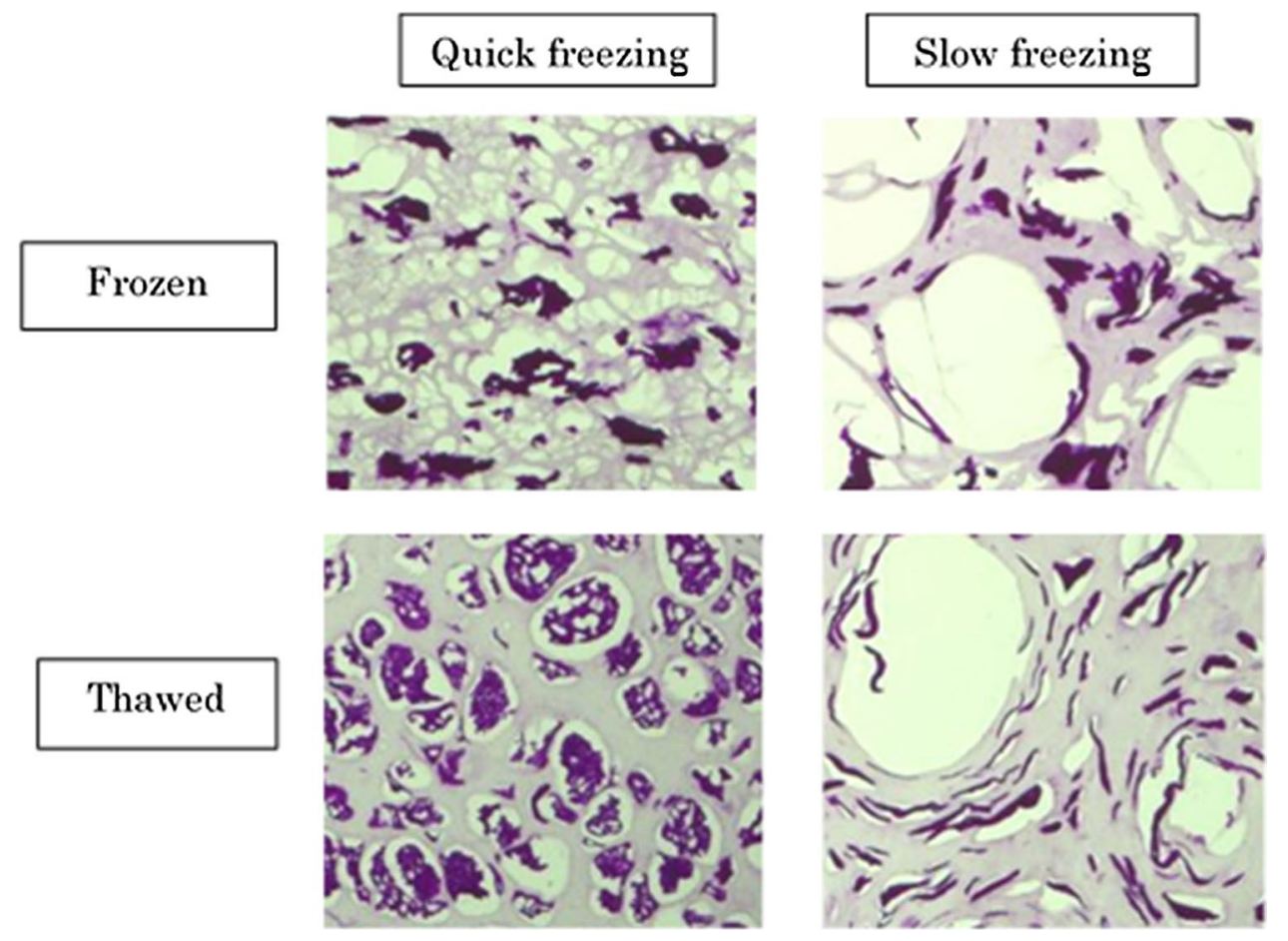

crystals and less thawing drip of surimi gel in commercial surimi product (Niu et al. 2016; 2020). This is probably due to the combined results of improved water holding capacity and ice crystal growth inhibition by strengthening the gel structure with the protein membrane surrounding fish oil particles (Gao et al. 2018).

As described above, various factors are related to the freezing tolerance of surimi-based products, and the formation of ice crystals is closely related to quality changes of these products.

\section{Technology aimed at quality improvements in frozen fish meat}

The performance of freezing machines has been dramatically improved, and ultra-low temperatures of $-60{ }^{\circ} \mathrm{C}$ or lower are now widely used. In addition, the effects of high pressures (Fernández et al. 2006; Tironi et al. 2007; Su et al. 2014), ultrasound (Zheng and Sun 2006; Cheng et al. 2015), antifreeze proteins (Hagiwara 2011; Hagiwara et al. 2017), super chilling (Kaale et al. 2011), supercooling (Miyawaki et al. 1992; Shimoyamada et al. 1999; Kobayashi et al. 2014), and other methods are currently being investigated to obtain instantaneous and homogenous ice crystals or prevent the formation of ice crystals.

On the other hand, in recent years, research focusing on biochemical changes that occur under subzero temperatures has also been conducted. The freezing of extremely fresh seafood products just before rigor mortis is one approach to improving quality and conserving energy; however, muscle contraction and drip loss due to thawing rigor are problems still encountered during the industrial production of frozen seafood with high quality. Thaw rigor is thought to be a muscle contraction phenomenon that occurs by utilizing the energy of residual ATP when calcium leaks from the sarcoplasmic reticulum to the muscle during thawing (Yamanaka et al. 1978; Ma and Yamanaka 1991; Ushio et al. 1991). It leads to intense muscle contraction, hardening of meat, substantial drip loss, and unfavorable properties (Fukuda and Okazaki 2013). The fisheries industry has endeavored to prevent this via holding fish for a certain period of time before freezing. However, the freshness of the fish decreases with this method, and there is a risk of further deterioration of quality. Therefore, an appropriate thawing method for fish meat is required to prepare fish meat with quality high enough for sashimi.

Meanwhile, studies on the thaw rigor of bonito (Bito 1978), sardine (Bito 1980), pollock (Cappeln et al. 2001), and chub mackerel (Moriya et al. 2019) have shown that thaw rigor is related to a rapid degradation of glycogen and decreased ATP concentration during rapid thawing. It is also indicated that thaw rigor can be prevented by treatment at subzero temperatures above $-10{ }^{\circ} \mathrm{C}$ for a certain period before thawing. It has been confirmed that this method is effective for frozen whale meat (Murata et al. 2008; Fukushima et al. 2018), frozen bigeye tuna meat (Imamura et al. 2012), and frozen chub mackerel (Moriya et al. 2019).

When nicotinamide adenine dinucleotide (NAD) disappears due to treatment at subzero temperatures before 

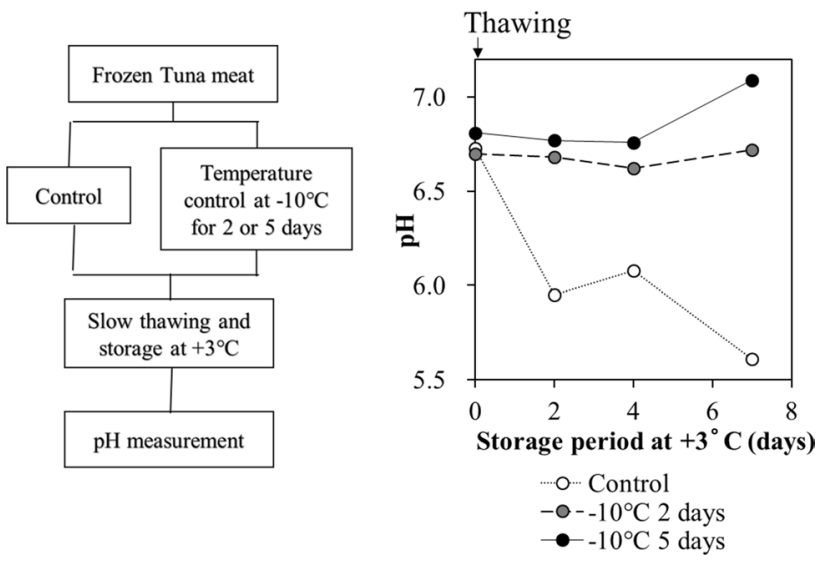

Fig. 11 Changes in $\mathrm{pH}$ of tuna before and after storage at $-10{ }^{\circ} \mathrm{C}$ for different durations $\left(0,2\right.$, and 5 days) and during storage at $3{ }^{\circ} \mathrm{C}$ after rapid thawing. The schematic of the experimental treatments for measurement and quality evaluation was shown in the left side. Partially reproduced from Fig. 4 in Nakazawa et al. (2016)

thawing, the $\mathrm{pH}$ of the thawed meat remains high, since the anaerobic glycolysis system is deactivated at the time of frozen thawing; the potential to improve the water holding capacity and texture of thawed meat has been confirmed for sardines (Bito 1980), bonito (Bito 1978) and bigeye tuna (Nakazawa et al. 2016) (Fig. 11). Tsukamasa et al. (2018) suggested that the suppression of the $\mathrm{pH}$ decrease by this treatment is effective for suppressing the progression of metmyoglobin formation in frozen bonito meat. However, a $\mathrm{pH}$ decrease was not prevented by this treatment in whale (Fukushima et al. 2018) and chub mackerel (Moriya et al. 2017). Moriya et al. (2017) proposed that the preventive effect on $\mathrm{pH}$ decrease by this temperature treatment was limited to fish species in which the decrease rate of NAD under subzero temperatures was rapid.

These findings indicated the potential for quality control of fish meat utilizing biochemical changes under freezing temperatures. The detailed mechanisms by this method are expected to be revealed in future studies.

\section{Summary}

Generally, the stability of fish and shellfish meat is lower than that of livestock meat, and the concept of T-TT (time-temperature-tolerance), including frozen storage temperature and storage period, is more important for maintaining quality of fish and shellfish meat.

Protein denaturation before and during freezing and frozen storage greatly affects the quality. When fish meat is stored at a sufficiently low temperature $\left(-40^{\circ} \mathrm{C}\right)$, protein denaturation of the frozen fish meat is suppressed and the tissue of the meat reabsorbs water.
Ice crystal formation in frozen seafood significantly affects the quality properties by changing the structure of tissues and other properties. However, the effects of ice crystals on the quality of thawed fish meat differ based on the fish species, post-mortem stages, protein denaturation of frozen fish meat, and processing conditions of frozen fish meat.

In the case of frozen fish products such as lightly salted fish or frozen kamaboko, changes in the protein properties and the tissue structure due to the conditions of processing; i.e. salting, heating, additives, freezing rate, storage temperatures, and the order of processing, have great effects on the formation and growth of ice crystals and the quality after thawing.

Understanding the changes in the pretreatment processes such as catching, cooling/freezing, storage, and thawing and their relationship with the resulting meat quality is necessary to selecting an optimum technology; however, some of this information has not yet been explicated. Thus, further research and technical development are required in order to elucidate appropriate freezing and storage conditions specific to the characteristics of each seafood product.

Acknowledgements Some of the work introduced in this paper was supported in part by the project "A Scheme to Revitalize Agriculture and Fisheries in Disaster Area through Deploying Highly Advanced Technology" from Ministry of Agriculture, Forestry and Fisheries, Japan, "Tohoku Marine Science Center Project" from Ministry of Education, Culture, Sports, Science and Technology, Japan, and Collaborative work with IDEA Consultants, Inc.

Open Access This article is licensed under a Creative Commons Attribution 4.0 International License, which permits use, sharing, adaptation, distribution and reproduction in any medium or format, as long as you give appropriate credit to the original author(s) and the source, provide a link to the Creative Commons licence, and indicate if changes were made. The images or other third party material in this article are included in the article's Creative Commons licence, unless indicated otherwise in a credit line to the material. If material is not included in the article's Creative Commons licence and your intended use is not permitted by statutory regulation or exceeds the permitted use, you will need to obtain permission directly from the copyright holder. To view a copy of this licence, visit http://creativecommons.org/licenses/by/4.0/.

\section{References}

Akahane Y, Shimizu Y (1990) Effects of setting incubation on the water-holding capacity of salt-ground fish meat and its heated gel. Nippon Suisan Gakkaishi 56:139-146 (in Japanese with English abstract)

Alizadeh E, Chapleau N, de Lamballerie M, Le-Bail A (2007) Effect of different freezing processes on the microstructure of Atlantic salmon (Salmo salar) fillets. Innov Food Sci Emerg Technol 8:493-499

Ando M, Miyoshi M (2002) Influence of freezing and thawing on the change in texture squid meat. J Home Econ Jpn 53(12):11-18

Añón MC, Calvelo A (1980) Freezing rate effects on the drip loss of frozen beef. Meat Sci 4:1-14 
Benjakul S, Bauer F (2001) Biochemical and physicochemical changes in catfish (Silurusglanis Linne) muscle as influenced by different freeze-thaw cycles. Food Chem 72:207-217

Bito M (1976) Studies on the retention of meat color of frozen tuna. Bull Tokai Reg Fish Re Lab 84:51-113 (in Japanese with English abstract)

Bito M (1978) Changes in NAD and ATP levels and pH in frozenstored skipjack meat, in relation to amount of drip. Nippon Suisan Gakkaishi 44:897-902 (in Japanese with English abstract)

Bito M (1980) Effect of degradation of NAD and ATP in frozen-stored sardine meat on the changes of $\mathrm{pH}$ and amount of drip in the thawed meat. Bull Tokai Reg Fish Re Lab 103:65-72 (in Japanese with English abstract)

Cappeln G, Nielsen J, Hamm R (2001) Glycolysis and ATP degradation in cod (Gadus morhua) at subzero temperatures in relation to thaw rigor. LWT 34:81-88

Cheng X, Zhang M, Xu B, Adhikari B, Sun J (2015) The principles of ultrasound and its application in freezing related processes of food materials: a review. Ultrason Sonochem 27:576-585

Codex International Food Standards (1989) Standard for quick frozen fish sticks (fish fingers), fish portions and fish fillets-codex stan 166. FAO Codex Alimetarious 6(2):3

Connell JJ (1968) The effect of freezing and frozen storage on the proteins of fish muscle. In: Hawthorne J, Rolfe EJ (eds) Low temperature biology of foodstuffs. Pergamon, Oxford, pp 333-358

Delbarre-Ladrat C, Chéret R, Taylor R, Verrez-Bagnis V (2006) Trends in postmortem aging in fish: understanding of proteolysis and disorganization of the myofibrillar structure. Crit Rev Food Sci Nutr 46:409-421

Einen O, Guerin T, Svein Olav Fjæra SO, Skjervold PO (2002) Freezing of prerigor fillets of Atlantic salmon. Aquaculture 212:129-140

Ertbjerg P, Puolanne E (2017) Muscle structure, sarcomere length and influences on meat quality: a review. Meat Sci 132:139-152

Fernández PP, Otero L, Guignon B, Sanz PD (2006) High-pressure shift freezing versus high-pressure assisted freezing: effects on the microstructure of a food model. Food Hydrocoll 20:510-522

Fukuda Y (1996) Denaturation by freezing of fish muscle proteins. Bull Natl Res Inst Fish Sci 8:77-79 (in Japanese with English abstract)

Fukuda Y (2006) Factor influencing on restoration of fish meat after thawing. Refrigeration 81:171-174 (in Japanese with English abstract)

Fukuda Y, Arai K (1994) Species specificity in cryostability of fish myofibrillar protein. Cryobiol Cryotechnol 40:35-38 (in Japanese with English abstract)

Fukuda Y, Okazaki E (2013) Seafood products. In: JSRAE handbook. Foods and biology, 6th edn, vol 6. The Japan Society of Refrigerating and AirConditioning Engineers, Tokyo, pp 177-191 (in Japanese)

Fukuda Y, Kakehata K, Arai K (1981) Denaturation of myofibrillar protein in deep-sea fish by freezing and storage. Nippon Suisan Gakkaishi 47:663-672 (in Japanese with English abstract)

Fukuda Y, Tarakita Z, Kawamura M, Kakehata K, Arai K (1982) Denaturation of myofibrillar protein in chub mackerel during freezing and storage. Nippon Suisan Gakkaishi 48:1627-1632 (in Japanese with English abstract)

Fukuda Y, Tarakita Z, Arai K (1984) Effect of freshness of chub mackerel on the freeze-denaturation of myofibrillar protein. Nippon Suisan Gakkaishi 50:845-852 (in Japanese with English abstract)

Fukuda Y, Okazaki E, Wada R (2006) Effect of fluctuations of temperature during frozen storage on denaturation of fish myofibrillar protein. Trans JSRAE 23:335-340 (in Japanese with English abstract)
Fukushima H, Nakazawa N, Yamada K, Matsumiya M, Wada R, Maeda $\mathrm{T}$ (2018) Biological metabolism of frozen whale meat at subzero temperatures in relation to thaw rigor. Trans JSRAE 35:135-139

Gao Y, Fukushima H, Deng S, Jia R, Osako K, Okazaki E (2018) Effect of emulsifying stability of myofibrillar protein on the gel properties of emulsified surimi gel. Food Sci Nutr 6:1229-1237

Hagiwara T (2011) Inhibition of recrystallization of ice crystals by addition of antifreeze proteins. Refrigeration 86:562-568 (in Japanese)

Hagiwara T, Kobayashi R, Kimizuka N (2017) Possible technologies for improving the quality of frozen marine products. In: Okazaki E, et al. (eds) Innovative technologies for improving the quality of marine products in frozen state-Gloval distribution of high quality marine products. Koseisha Koseikaku, Tokyo, pp 90-111 (in Japanese)

Hanzawa R, Fukuda Y (2006) Improvement of quality by new loin feezing tuna. Refrigeration 81:204-207 (in Japanese)

Hashimoto A, Arai K (1985) The effect of pH on the thermostability of fish myofibrils. Nippon Suisan Gakkaishi 51:99-105 (in Japanese with English abstract)

Hashimoto K, Takiguchi A (2015) Effect of the freshness and freezing temperature on the ice crystal formation in spotted mackerel Scomber Australasicus. Trans JSRAE 32:57-63 (in Japanese with English abstract)

Ichisaki E, Kuwahara K, Okamoto A, Okazaki E (2011) Effects of soaking conditions on water release from thawed jack mackerel meat. Nippon Suisan Gakkaishi 77:89-93 (in Japanese with English abstract)

Imamura S, Suzuki M, Okazaki E, Murata Y, Kimura M, Kimiya T, Hiraoka Y (2012) Prevention of thaw-rigor during frozen storage of bigeye tuna Thunnus obesus and meat quality evaluation. Fish Sci 78:177-185

Indergard E, Tolstorebrov I, Larsen H, Eikevik TM (2014) The influence of long-term storage, temperature and type of packaging materials on the quality characteristics of frozen farmed Atlantic Salmon (Salmo Salar). Int J Refrig 41:27-36

Inohara K, Kimura I, Yuan C (2013) Suppressive effect of ATP on autoxidation of tuna oxymyoglobin to metmyoglobin. Fish Sci 79:503-511

Inohara K, Kurogi S, Onoue Y, Hamada M, Tamotsu S, Kimura I (2014) Suppressive effect of ATP contained in muscle on the browning of amberjack Seriola dumerili dark muscle during frozen storage. Nippon Suisan Gakkaishi 80:965-972 (in Japanese with English abstract)

Jia R, Eguchi M, Ding W, Nakazawa N, Osako K, Okazaki E (2018a) Quality changes of commercial surimi-based products after frozen storage. Trans JSRAE 35:205-210

Jia R, Hiraoka Y, Tung Y, Nakazawa N, Osako K, Okazaki E (2018b) "Setting-Freezing-Reheating" procedure improves the gel properties of frozen starch-surimi gel. Food Sci Technol Res 24:999-1006

Jia R, Katano T, Yoshimoto Y, Gao Y, Watanabe Y, Nakazawa N, Osako K, Okazaki E (2018c) Sweet potato starch with low pasting temperature to improve the gelling quality of surimi gels after freezing. Food Hydrocoll 81:467-473

Jia R, Jiang Q, Kanda M, Tokiwa J, Nakazawa N, Osako K, Okazaki E (2019) Effects of heating processes on changes in ice crystal formation, water holding capacity, and physical properties of surimi gels during frozen storage. Food Hydrocoll 90:254-265

Jiang Q, Okazaki E, Zheng J, Que T, Chen S, Hu Y (2018a) Structure of northern snakehead (Channa argus) meat: Effects of freezing method and frozen storage. Int J Food Prop 21:1166-1179

Jiang Q, Jia R, Nakazawa N, Hu Y, Osako K, Okazaki E (2018b) Changes in protein properties and tissue histology of tuna meat as affected by salting and subsequent freezing. Food Chem 271:550-560 
Jiang Q, Nakazawa N, Hu Y, Osako K, Okazaki E (2019a) Microstructural modification and its effect on the quality attributes of frozen-thawed bigeye tuna (Thunnus obesus) meat during salting. LWT 100:213-219

Jiang Q, Nakazawa N, Hu Y, Osako K, Okazaki E (2019b) Changes in quality properties and tissue histology of lightly salted tuna meat subjected to multiple freeze-thaw cycles. Food Chem 293:178-186

Kaale LD, Eikevik TM (2013) A histological study of the microstructure sizes of the red and white muscles of Atlantic salmon (Salmo salar) fillets during superchilling process and storage. J Food Eng 114:242-248

Kaale LD, Eikevik TM, Rustad T, Kolsaker K (2011) Superchilling of food: a review. J Food Eng 107:141-146

Kato S (1985) An appraisal of features in each of 4 topical food preservation systems in Japan as compared with conventional food freezing. Refrigeration 60:1005-1025 (in Japanese)

Kin S, Schilling MW, Smith BS, Silva JL, Jackson V, Kim TJ (2010) Phosphate type affects the quality of injected catfish fillets. J Food Sci 75:74-80

Kobayashi R, Kanesaka N, Watanabe M, Suzuki T (2014) Effect of the breaking temperature of supercooling on ice characteristics and drip loss of foods in supercooled freezing method. Trans JSRAE 31:297-303 (in Japanese with English abstract)

Kominami Y, Watanabe M, Suzuki T (2014) Effects of postmortem physiological changes on ice crystal morphology in the fish muscle tissue. Trans JSRAE 31(2):47-56 (in Japanese with English abstract)

Leygonie C, Britz TJ, Hoffman LC (2012) Impact of freezing and thawing on the quality of meat: review. Meat Sci 91(2):93-98

Love RM (1966) Protein denaturation in frozen fish. XI. The proportion of tissue water converted to ice. J Sci Food Agric 17:465-471

Love RM (1968) Ice formation in frozen muscle. In: Hawthorne J, Rolfe EJ (eds) Low temperature biology of foodstuffs. Pergamon, Oxford, pp 105-123

Love RM, Haraldsson SB (1961) The expressible fluid of fish fillets. XI.-Ice crystal formation and cell damage in cod muscle frozen before rigor mortis. J Sci Food Agric 12:442-449

Ma LB, Yamanaka H (1991) Studies of thaw-rigor in red-sea bream and carp muscles. Nippon Suisan Gakkaishi 57:1365-1368

Martino MN, Otero L, Sanz PD, Zaritzky NE (1998) Size and location of ice crystals in pork frozen by high-pressure-assisted freezing as compared to classical methods. Meat Sci 50(3):303-313

Miyawaki O (2018) Water and freezing in food-a review. Food Sci Technol Res 24:1-21

Miyawaki O, Abe T, Yano T (1992) Freezing and ice structure formed in protein gels. Biosci Biotechnol Biochem 56:953-957

Moriya K, Nakazawa N, Osako K, Okazaki E (2017) Influence of subzero temperature treatment before thawing on anaerobic metabolism, $\mathrm{pH}$ and dark meat color in frozen chub mackerel Scomber japonicus. Nippon Suisan Gakkaishi 83:785-794 (in Japanese with English abstract)

Moriya K, Nakazawa N, Osako K, Okazaki E (2019) Effect of subzero temperature treatment at $-2{ }^{\circ} \mathrm{C}$ before thawing on prevention of thaw rigor, biochemical changes and rate of ATP consumption in frozen chub mackerel (Scomber japonicus). LWT 114:108396

Murata Y, Ogiwara M, Funahashi H, Ueno K, Okazaki E, Kimura I, Fukuda Y (2008) Development of thawing method for frozen whale meat with high concentration of ATP. J Fish Technol 1:37-41 (in Japanese with English abstract)

Nakazawa N, Fukuda Y (2012) Quality evaluation indexes and mesuring methods of frozen fish meat. Refrigeration 87:26-132 (in Japanese)

Nakazawa N, Fukushima H, Wada R, Fukuda Y, Okazaki E (2016) Maintenance of $\mathrm{pH}$ and quality of thawed bigeye tuna meat by temperature control before thawing. Trans JSRAE 33:97-204 (in Japanese with English abstract)

Nakazawa N, Wada R, Fukushima H, Tanaka R, Kono S, Okazaki E (2020) Effect of long-term storage, ultra-low temperature, and freshness on the quality characteristics of frozen tuna meat. Int $\mathbf{J}$ Refrig 112:270-280

Ngapo TM, Babare IH, Reynolds J, Mawson RF (1999) Freezing rate and frozen storage effects on the ultrastructure of samples of pork. Meat Sci 53:159-168

Niu L, Huong HTT, Ru J, Gao Y, Nakazawa N, Osako K, Okazaki E (2016) Effects of emulsifying fish oil on the water holding capacity and ice crystal formation of heat-induced gel during frozen storage. Food Sci 20:293-298

Niu L, Suzuki Y, Fukushima H, Nakazawa N, Osako K, Okazaki E (2020) Fish oil supplementation improves the quality of frozen sasa-kamaboko. Food Sci Technol Res 26 (in Press)

Ogata Y, Shindo J, Kimura I (2012) Suppression effect of ATP on freeze denaturation of fish myofibrillar protein. Nippon Suisan Gakkaishi 78:461-467 (in Japanese with English abstract)

Okazaki E (2009) Freezing of seafood products. In: Food refrigeration technology. JSRAE, Tokyo, pp 67-109 (in Japanese)

Ooizumi T, Kawase M, Akahane Y (2003) Permeation of sodium chloride into fish meat and its effect on moisture content as a function of the osmotic pressure of the soaking solution. Fish Sci 69:830-835

Shenouda SYK (1980) Theories of protein denaturation during frozen storage of fish flesh. Adv Food Res 26:275-311

Shimoyamada M, Tomatsu K, Watanabe K (1999) Effect of precooling step on formation of soymilk freeze-gel. Food Sci Technol Res 5:284-288

Su G, Ramaswamy HS, Zhu S, Yu Y, Hu F, Xu M (2014) Thermal characterization and ice crystal analysis in pressure shift freezing of different muscle (shrimp and porcine liver) versus conventional freezing method. Innov Food Sci Emerg Technol 26:40-50

Suzuki M, Kimiya T, Okazaki E, Hiraoka Y, Omura Y, Uehara T, Yokota Y, Sawada K, Fusejima I, Imamura S (2015) Quality evaluation of frozen tuna caught in a tuna longline fishery. 1st report: the difference of distribution of chemical components. Trans JSRAE 32:65-74 (in Japanese with English abstract)

Tanaka T (1969) Relationship between freshness before freezing and cold storage deterioration in the North Pacific Alaska PollackI. Bull Tokai Reg Fish Re Lab 60:143-168 (in Japanese with English abstract)

Tanaka T (1985) Studies on the condition and the mechanism related with the spongy meat formation in the frozen cod and its preventive treatments. Bull Tokai Reg Fish Re Lab 116:67-224 (in Japanese with English abstract)

Tanaka T, Kakuda K, Nishiwaki K, Nakayama T, Otsuka Y (1977) Influence of the biological conditions of skipjack as the raw materials and handling before freezing on board upon the final quality of the frozen fish. Refrigeration 52:3-24 (in Japanese with English abstract)

Thorarinsdottir KA, Gudmundsdottir G, Arason S, Thorkelsson G, Kristbergsson K (2004) Effects of added salt, phosphates, and proteins on the chemical and physicochemical characteristics of frozen cod (Gadus morhua) fillets. J Food Sci 69:144-152

Thorarinsdottir KA, Arason S, Sigurgisladottir S, Valsdottir T, Tornberg E (2011) Effects of different pre-salting methods on protein aggregation during heavy salting of cod fillets. Food Chem 124:7-14

Tironi V, Le Bail A, de Lamballerie M (2007) Effects of pressure-shift freezing and pressure-assisted thawing on sea bass (Dicentrarchus labrax) quality. J Food Sci 72:C381-C387 
Tolstorebrov I, Eikevik TM, Bantle M (2016) Effect of low and ultralow temperature applications during freezing and frozen storage on quality parameters for fish. Int J Refrig 63:37-47

Tsukamasa Y, Nakamura K, Nagato T, Yamamoto K, Morita T, Hiraoka T, Fukuda T, Itoh T, Ando M (2018) Study on the delay of discoloration of frozen skipjack Katsuwonus pelamis meat. Nippon Suisan Gakkaishi 84:111-118 (in Japanese with English abstract)

Ushio H, Watabe S, Iwamoto M, Hashimoto K (1991) Ultrastructural evidence for temperature dependent $\mathrm{Ca}^{2+}$ release from fish sarcoplasmic reticulum during rigor mortis. Food Struct 10:267-275

Yamanaka H, Nakagawasai T, Kikuchi T, Amano K (1978) Studies on the contraction of carp muscle-VI remarkable differences between rigor mortis and thaw rigor. Nippon Suisan Gakkaishi 44:11231126 (in Japanese with English abstract)

Yamazawa M (1991) Relationship between the water-absorbing ability of starch granules and their kamaboko-gel reinforcing effect.
Nippon Suisan Gakkaishi 57:965-970 (in Japanese with English abstract)

Yoshioka T, Arai K (1986) Protective effect of ATP- $\mathrm{MgCl}_{2}$ on thermal denaturation of myosins from rabbit and tilapia muscles. Nippon Suisan Gakkaishi 52:1829-1836 (in Japanese with English abstract)

Zheng L, Sun DW (2006) Innovative applications of power ultrasound during food freezing processes-a review. Trends Food Sci Technol 17:16-23

Publisher's Note Springer Nature remains neutral with regard to jurisdictional claims in published maps and institutional affiliations. 